\title{
ANALISIS SISTEM INFORMASI GEOGRAFIS UNTUK PENENTUAN LOKASI TEMPAT PEMROSESAN AKHIR SAMPAH DI KABUPATEN LOMBOK TIMUR
}

\author{
Siti Malikah ${ }^{*}$, Baiq Liana Widiyanti², Baiq Ahda Razula Apriyeni ${ }^{3}$, Hasrul Hadi ${ }^{4}$ \\ 1,4Program Studi Pendidikan Geografi, Fakultas Ilmu Sosial dan Ekonomi, Universitas Hamzanwadi, Selong, Indonesia \\ 2Program Studi Teknik Lingkungan, Fakultas Teknik, Universitas Hamzanwadi, Selong, Indonesia \\ ${ }^{3}$ Program Studi Pariwisata, Fakultas Bahasa, Seni dan Humaniora, Universitas Hamzanwadi, Selong, Indonesia \\ *Email Koresponden: malikahsiti97@gmail.com
}

Diterima: 26-11-2020, Revisi: 19-12-2020, Disetujui: 21-12-2020

(C)2020 Program Studi Pendidikan Geografi, FISE, Universitas Hamzanwadi

\begin{abstract}
Abstrak Peningkatan jumlah penduduk di Kabupaten Lombok Timur berpengaruh terhadap peningkatan volume sampah, sedangkan Tempat Pemrosesan Akhir Sampah (TPAS) yang ada tidak mampu lagi menampung volume sampah yang terus meningkat. Pemerintah juga belum mendapatkan rekomendasi lokasi yang sesuai untuk pembangunan TPAS yang baru, oleh karena itu sangat penting dilakukan sebuah analisis kesesuain untuk pendirian TPAS baru di Kabupaten Lombok Timur guna menanggulangi tingginya volume sampah di TPAS yang lama. Penelitian ini bertujuan untuk menentukan lokasi yang sesuai untuk pembangunan TPAS. Penelitian ini merupakan penelitian deskriptif kuantitatif berbasis sistem informasi geografis (SIG). Penentuan parameter untuk analisis kesesuaian lokasi TPAS menggunakan Standar Nasional Indonesia (SNI) Nomor 03-3241-1994. Teknik analsis data menggunakan overlay atau tumpang susun beberapa peta menggunakan aplikasi ArcGIS versi 10.1. Proses analisis terbagi dalam tiga tahap yaitu: 1) tahap regional, merupakan tahap seleksi awal untuk mengetahui kelas kesesuaian lahan; 2) tahap penyisih, pada tahap ini dilakukan penyisihan kembali dari hasil pada tahap pertama dengan menggunakan nilai dan bobot dari parameter umum dan parameter fisik; 3) tahap rekomendasi lokasi yang sesuai. Berdasarkan hasil analisis data diketahui bahwa lokasi yang sesuai untuk dijadikan TPAS di Kabupaten Lombok Timur adalah Kecamatan Pringgabaya dengan skor nilai 164.
\end{abstract}

Kata kunci: analisis SIG, TPAS, Lombok Timur

\begin{abstract}
The increase of population in East Lombok Regency has an effect on the increase in the volume of waste, while the existing Waste Final Processing Sites (WFPS) are no longer able to accommodate the increasing volume of waste. The government also has not yet received a suitable location recommendation for the construction of a new WFPS, therefore it is very important to carry out a suitability analysis for the establishment of a new WFPS in East Lombok Regency to overcome the high volume of waste in the old WFPS. This study aims to determine a suitable location for WFPS development. This research is a quantitative descriptive study based on Geographic Information Systems (GIS). Determination of parameters for the analysis of the suitability of WFPS locations using the Indonesian National Standard (INS) Number 03-3241-1994. Data analysis technique uses overlay several maps using ArcGIS version 10.1 application. The analysis process is divided into three stages, namely: 1) the regional stage, which is the initial selection stage to determine the land suitability class; 2) the elimination stage, at this stage the elimination is carried out from the results in the first stage by using the values and weights of general parameters and physical parameters; 3) the appropriate location recommendation phase. Based on the results of data analysis, it is known that the suitable location to become WFPS in East Lombok. Regency is Pringgabaya District with 164 score.
\end{abstract}

Keywords: GIS analysis, WFPS,Lombok Timur

\section{PENDAHULUAN}

Keberadaan sampah tidak dapat dipisahkan dari berbagai aktivitas kehidupan yang dijalani oleh manusia. Meningkatnya volume sampah tentunya juga beriringan dengan semakin bertambahnya jumlah penduduk (Mahyudin, 2017). Semakin bertambahnya jumlah penduduk memicu bertambah dan 
beragamnya kebutuhan hidup penduduk yang mana dari kebutuhan tersebut kemudian menimbulkan zat sisa yang disebut sampah. Jika tidak dikelola dengan baik, maka peningkatan volume sampah ini dapat menjadi permasalahan yang terus berlanjut. Dampak yang ditimbulkan dapat berupa menurunnya kualitas lingkungan seperti menurunnya keindahan, kenyamanan, munculnya wabah penyakit, dan dampak negatif lainnya (Hasibuan, 2016; Shofa \& Hadi, 2017).

Menurut Sudrajat (2007), setidaknya ada 7 faktor yang menjadi penyebab munculnya permasalahan sampah: 1) volume sampah sangat besar sehingga melebihi kapasitas daya tampung tempat pembuangan akhir sampah (TPAS); 2) lahan TPAS semakin sempit karena tergeser tujuan penggunaan lain; 3) teknologi pengelolaan sampah tidak optimal sehingga sampah lambat membusuknya. Hal ini menyebabkan percepatan peningkatan volume sampah lebih besar dari pembusukannya. Oleh sebab itu selalu diperlukan perluasan areal TPAS baru; 4) Sampah yang sudah matang dan telah berubah menjadi kompos tidak dikeluarkan dari TPAS karena berbagai pertimbangan; 5) Manajemen pengelolaan sampah tidak efektif sehingga sering kali menjadi penyebab distrorsi dengan masyarakat setempat; 6) pengelolaan sampah dirasakan tidak memberikan dampak positif kepada lingkungan; dan 7) kurangnya dukungan kebijakan dari pemerintah, terutama dalam memanfaatkan produk sampingan dari sampah sehingga menyebabkan tertumpuknya produk tersebut di TPAS.

Permasalahan sampah banyak terjadi di berbagai daerah di Indonesia, tak terkecuali di Kabupaten Lombok Timur, Nusa Tenggara Barat. Kabupaten Lombok Timur tercatat sebagai kabupaten tertinggi jumlah penduduknya di NTB. Begitu pula dengan pertumbuhan pertahunnya yang terus meningkat. Jika dibandingkan, jumlah penduduk Kabupaten Lombok Timur pada tahun 2010 berjumlah 1.105 .582 jiwa. Sedangkan pada tahun 2020 berjumlah 1.208.594 jiwa (BPS NTB, 2020). Sehingga dapat diketahui dalam kurun waktu sepuluh tahun terjadi pertambahan jumlah penduduk yang cukup signifikan, yaitu sebanyak 103.012 jiwa. Tingginya jumlah dan pertumbuhan jumlah penduduk Kabupaten Lombok Timur tentunya menjadi pemicu semakin meningkatnya volume sampah per harinya. Menurut data dari Dinas Lingkungan Hidup dan Kebersihan (DLHK) Lombok Timur, tercatat sebanyak 515 ton sampah per hari diangkut menuju TPAS Ijo Balit (insidelombok.com, 2020).

Kabupaten Lombok Timur saat ini hanya memiliki satu lokasi TPAS yang berada di Desa Ijo Balit, Kecamatan Labuhan Haji. TPAS di Ijo Balit yang diresmikan pada tanggal 17 Desember 2001 ini sudah terlalu lama beroperasi dan terancam overload. Lahan seluas $9 \mathrm{Ha}$ tidak lagi bisa menampung sampah hingga akhir tahun 2019. Diperlukan setidaknya 5 Ha lahan tambahan baru untuk menampung sampah yang setiap harinya masuk sebanyak 50 ribu kubik atau setara dengan 60 ton sampah (DLHK Lombok Timur, 2018). Pada tahun 2017, ketinggian tumpukan sampah di TPAS Ijo Balit mencapai 7 meter. TPAS ini juga pernah jebol dan meluber ke lahan warga. Kondisi tersebut menimbulkan permasalahan baru terkait sampah. TPAS yang sudah ada tidak lagi bisa menampung sampah yang dihasilkan dan memerlukan TPAS yang baru. TPAS yang baru diharapkan mampu menampung sampah yang dihasilkan masyarakat Kabupaten Lombok Timur (Suara NTB, 2017). Kebutuhan TPAS yang baru tidak bisa langsung ditetapkan begitu saja. TPAS yang akan dibangun perlu memperkirakan dampak yang dapat ditimbulkan saat beroperasi maupun setelah beroperasi. Pendugaan dampak ini berkaitan dengan penerapan kriteria pemilihan TPAS. Penetapan dan pendirian TPAS memiliki kriteriakriteria yang harus dipenuhi.

Beberapa penelitian telah dilakukan mengenai pengelolaan sampah maupun TPAS. Huda et al., (2020) misalnya melakukan penelitian mengenai bagaimana pengelolaan sampah kawasan sempadan sungai yang melewati dua kelurahan, yaitu Kelurahan Pancor dan Sekarteja. Ia memfokuskan kajiannya pada bagaimana warga maupun pihak pemerintah kelurahan melakukan upaya pengelolaan sampah mulai dari hulu sampai hilir di kawasan sempadan sungai. Ia menemukan bahwa terdapat beberapa kebiasaan yang dilakukan warga dalam mengelola sampah, yaitu 1) sebagian menimbun dan membuangnya ke TPAS melalui petugas dengan membayar iuran, 2) sebagian membakar di halaman rumah/kebun, 3) membuang langsung ke kali/sungai. Irawan \& Yudono (2014) melakukan penelitian mengenai Studi Kelayakan Penentuan Tempat Pemrosesan Akhir Sampah (TPAS) di Pulau Bintan Propinsi Kepulauan Riau. Dalam metode penelitiannya menggunakan standar SNI dan pendekatan Sistem Informasi Geografis. Hanya saja dalam kesimpulannya masih belum spesifik menemukan satu lokasi yang paling layak untuk dijadikan TPAS baru. Handono (2010) juga melakukan penelitian mengenai Model Pengelolaan Tempat Pemrosesan Akhir Sampah (TPAS) Secara Berkelanjutan di 
TPAS Cipayung Kota Depok, Jawa Barat. Dalam penelitiannya, ia hanya memfokuskan pada permasalahan dan proses pengelolaan sampah di TPAS Cipayung. Cukup berbeda dari penelitian sebelumnya, penelitian terkait penentuan lokasi TPAS di Lombok Timur ini fokus pada standar SNI dan pendekatan Sistem Informasi Geografis (SIG) sampai menemukan di desa dan kecamatan mana yang sekiranya paling layak untuk dijadikan lokasi pembangunan TPAS baru di Kabupaten Lombok Timur.

Upaya untuk menemukan lokasi yang tepat untuk pembangunan TPAS baru di Kabupaten Lombok Timur harus dilakukan dengan teliti dan ilmiah. Sehingga penelitian ini bertujuan untuk menemukan lokasi pembangunan TPAS baru yang layak di Kabupaten Lombok Timur. Terutama dengan pendekatan SIG dan standar SNI. Sehingga diharapkan dengan hasil penelitian ini akan dapat dijadikan bahan masukan kebijakan penentuan lokasi pembangunan TPAS yang baru oleh pemerintah Kabupaten Lombok Timur, Provinsi Nusa Tenggara Barat.

\section{METODE PENELITIAN}

Penelitian ini dilaksanakan di Kabupaten Lombok Timur dari bulan Agustus 2019 hingga Juni 2020. Metode yang digunakan adalah observasi dan studi dokumen dengan analisis Sistem Informasi Geografis (SIG). Data yang dikumpulkan dari kegiatan observasi antara lain data kondisi TPAS Ijo Balit sebagai TPAS utama di Kabupaten Lombok Timur yang sudah hampir overload. Sedangkan teknik studi dokumen yang digunakan yaitu mengumpulkan data-data berupa dokumen-dokumen yang dibutuhkan seperti dokumen profil Kabupaten Lombok Timur, Peta tematik yang relevan dengan topik penelitian ini seperti Peta Wilayah Administrasi Kabupaten Lombok Timur, Peta Geologi, Peta Rawan Bencana Alam, Peta Hidrologi, Peta Topografi, Peta Curah Hujan, dan Peta Penggunaan Lahan Kabupaten Lombok Timur. Data-data dokumen tersebut diperoleh dari instansi terkait seperti BAPPEDA, dinas PUPR, DLHK dan BPS Kabupaten Lombok Timur.

Teknik analisis data yang digunakan pada penelitian ini adalah overlay atau tumpang susun beberapa peta dengan menggunakan aplikasi ArcGIS versi 10.1. Tujuan analisis data ini adalah untuk menyederhanakan data ke dalam bentuk yang lebih mudah dibaca dan diinterpretasikan (Singarimbun, 1989 dalam Apriyeni, 2008). Penentuan lokasi TPAS yang sesuai ini menggunakan pedoman SNI Nomer 03-3241-1994 yang disusun oleh Badan Penelitian dan Pengembangan (Balitbang) Pekerjaan Umum (PU) tahun 1994. Menurut pedoman SNI tersebut terdapat ketentuan dalam menentukan lokasi TPAS: 1) TPAS tidak boleh berlokasi di danau, sungai, dan laut; 2) disusun berdasarkan tiga tahapan, yaitu tahap regional, tahap penyisihan, dan tahap rekomendasi. Ke tiga tahapan tersebut akan dijelaskan sebagai berikut:

1. Tahap Regional

Tahap regional merupakan tahap pertama dan merupakan kriteria untuk menentukan suatu zona layak atau tidak layak dijadikan lokasi TPAS. Beberapa parameter yang digunakan yaitu: 1) Kondisi geologi dengan syarat tidak berlokasi pada zona Holocene fault dan tidak boleh berada pada zona bahaya geologi. 2) Kondisi hidrologi, dengan syarat tidak boleh mempunyai muka air tanah kurang dari 3 meter; tidak boleh kelulusan tanah lebih dari $10^{-9} \mathrm{~cm} / \mathrm{det}$; jarak terhadap sumber air minum harus lebih dari 100 meter di hilir aliran; dan jika tidak ada zona yang memenuhi keriteriakriteria tersebut di atas, maka harus diadakan masukan teknologi. 3) Dari segi kemiringan zona harus kurang dari 20 persen. 4) Jarak dari lapangan terbang harus lebih besar dari 3.000 meter untuk penerbangan turbo jet, dan harus lebih besar dari 1.500 meter untuk jenis lain. 5) TPAS tidak boleh dibangun pada daerah lindung/cagar alam dan daerah banjir dengan periode ulang 25 tahun.

Pada tahap regional ini, setelah dilakukan skoring terhadap parameter-parameter yang sudah ditentukan, maka selanjutnya dilakukan penentuan kelas interval (Ki). Perhitungan dalam penentuan kelas kesesuaian lokasi TPAS adalah dengan hasil skoring dari kesesuaian lahan. Jumlah skoring adalah penjumlahan pada masing-masing kriterianya dan menentukan kelas interval yang diinginkan dengan cara mengurangi skor tertinggi dengan skor terendah, kemudian membaginya dengan jumlah interval yang diinginkan. Perhitungan tersebut menggunakan rumus/formula yang dirumuskan oleh Sturgess dalam Rachmah et al., (2018), yaitu : 


$$
K i=\frac{X t-X r}{k}
$$

Keterangan:

$\mathrm{Ki}=$ Kelas interval

$\mathrm{Xt}=$ Data Tertinggi

$\mathrm{Xr}=$ Data Terendah

$\mathrm{K}=$ Kelas yang diinginkan

2. Tahap Penyisihan

Tahap kedua yaitu tahap penyisihan yang merupakan tahap lanjutan dari tahap regional. Pada tahapan ini akan diberikan nilai pada lokasi dengan nilai tertinggi pada tahap regional. Tahap penyisihan menggunakan parameter sebagai berikut: 1) Iklim meliputi: Hujan (intensitas hujan, semakin kecil dinilai semakin baik), Angina (arah angin dominan tidak menuju ke permukaan dinilai semakin baik); 2) Utilitas (tersedia lebih lengkap dinilai semakin baik); 3) Lingkungan hidup meliputi: Habitat (kurang bervariasi, dinilai semakin baik), Daya dukung (kurang menunjang kehidupan flora dan fauna, dinilai semakin baik); 3) Kondisi tanah meliputi: Produktivitas tanah (tidak produktif dinilai lebih tinggi), Kapasitas dan umur (dapat menampung lahan lebih banyak dan lebih lama dinilai lebih baik), Ketersediaan tanah penutup (mempunyai tanah penutup yang cukup dinilai lebih baik), Status tanah (makin bervariasi dinilai tidak baik); 4) Demografi (kepadatan penduduk lebih rendah dinilai semakin baik); 5) Batas administrasi (dalam batas administrasi dinilai semakin baik); 6) Kebisikngan (semakin banyak zona penyangga dinilai semakin baik); 7) Bau (semakin banyak zona penyangga dinilai semakin baik); 8) Estetika (semakin tidak terlihat dari luar dinilai semakin baik); dan 9) Ekonomi (semakin kecil biaya satuan pengelolaan sampah (per $\mathrm{m}^{3} /$ ton) dinilai semakinbaik).

Setelah dilakukan skoring dan penentuan kelas interval, selanjutnya dilakukan tahapan overlay peta-peta yang sesuai dengan parameter yang ditentukan. Metode ini untuk menyeleksi wilayah yang sesuai untuk dijadikan lokasi TPAS.

3. Tahap Rekomendasi

Tahap ini merupakan tahap akhir sebagai hasil analisis pada tahap sebelumnya. Pada tahap ini telah dapat ditentukan di mana lokasi yang layak untuk dijadikan lokasi TPAS.

\section{TEMUAN DAN PEMBAHASAN}

Proses analisis penentuan lokasi TPAS yang sesuai di Kabupaten Lombok Timur didasarkan pada indikator SNI nomer 03-3241-1994. Penentuan lokasi TPAS ini dilakukan dalam tiga tahapan yaitu tahap regional, penyisihan dan rekomendasi. Nilai tertinggi dari indikator tersebut kemudian dijadikan sebagai hasil dalam penetapan lokasi yang terpilih.

\section{Tahap Regional}

Tahap ini merupakan tahap penyaringan awal yang menghasilkan tingkat kesesuaian lokasi TPAS menjadi tiga kelas kesesuaian. Hasil pada kelas sesuai menjadi pilihan untuk kembali dianalisis pada tahap selanjutnya. Sehingga hasil pada tahap ini secara regional diharapkan dapat mendefinisikan wilayah yang terpilih dianggap sesuai untuk dijadikan lokasi TPAS di Kabupaten Lombok Timur. Beberapa indikator yang digunakan untuk menentukan tingkat kesesuaian lokasi TPAS pada tahap regional ini antara lain kondisi geologi, kondisi hirogeologi, kemiringan lereng, jarak terhadap lapangan terbang, dan daerah lindung/cagar alam dan bahaya banjir.

1. Kondisi Geologi

Kondisi geologi sebagai parameter penelitian terdiri dari bahaya geologi seperti rawan gempa bumi, zona vulkanik aktif, daerah longsor, dan erosi serta rawan tsunami. Lokasi dengan bahaya geologi ini dihindari untuk mencegah terjadinya kerusakan terhadap pengolahan sampah dan kontruksi bangunan TPAS yang akan dibangun. Wilayah yang minim terjadi bencana alam dapat mencegah terjadinya kerusakan terhadap kontruksi bangunan TPAS serta tidak mengganggu proses pengelolaan sampah. Berdasarkan kondisi Kabupaten Lombok Timur, termasuk daerah yang rawan bencana dan untuk kerawanan terhadap bencana memang tidak dapat dihindari secara maksimal, jadi setiap wilayah memiliki kerentanan terhadap bencana geologi. Keberadaan Gunung Rinjani yang merupakan gunung api aktif di wilayah Kabupaten Lombok Timur dapat menjadi salah satu parameter kerawanan bencana gunung meletus. Selain itu Kabupaten Lombok Timur juga rawan 
terhadap gempa bumi, bahkan pada tahun 2018 terjadi gempabumi yang berdampak cukup parah di bagian utara Kabupaten Lombok Timur. Namun meskipun terjadi bencana gempabumi namun tidak pernah terjadi bencana tsunami. Meskipun demikian mengingat jenis bencana geologi sangat sulit diperediksi maka tetap harus dibangun TPAS baru. Secara keseluruhan wilayah Kabupaten Lombok Timur secara geologis termasuk kategori zona cukup sesuai untuk dijadikan lokasi TPAS.

\section{Kondisi Hidrologi}

Kondisi hidrologi ini ditujukan untuk mengantisipasi penyebaran lindi sampah yang bisa saja mencemari air tanah, maka diharapkan kondisi ini dapat dihindari. Berdasarkan kondisi ini, lokasi TPAS tidak boleh memiliki muka air tanah kurang dari 3 meter. Kelulusan tanah tidak boleh lebih dari $10^{-9} \mathrm{~cm} /$ det. Tidak berdekatan dengan sumber air minum, derah sungai, waduk dan pantai. Analisis ini dapat dilakukan dengan menganalisis wilayah berdasarkan jenis tanah dan jenis batuannya. Karena kondisi hidrogeologi ini juga dipengaruhi oleh keadaan geologi wilayah. Lokasi TPAS yang sesuai sebaiknya memiliki formasi batuan lempung dan lanau yang memiliki sifat permeabilitas rendah. Tanah dengan permeabilitas tinggi memiliki nilai rendah untuk dijadikan lokasi TPAS, karena memberikan perlindungan yang kecil terhadap air tanah. Jenis tanah ini akan berpengaruh pada permeabilitas terhadap air yang masuk ke dalam tanah.

Untuk mengetahui kelas kesesuaian berdasarkan jenis tanah, diperlukan peta jenis tanah Kabupaten Lombok Timur. Tanah yang merupakan jenis tanah alfisols adalah jenis tanah yang memiliki kejenuhan basa sedang hingga tinggi, umumnya berasal dari bahan induk vulkanis dan terletak di bawah kondisi iklim tropis basah. Jenis tanah ini juga merupakan tanah dengan tingkat kesuburan yang tinggi, drainase yang cukup baik dengan tekstur berkisar antara sedang hingga halus, biasanya berupa tanah latosol atau mediteran merah kuning. Hambatan pada pemanfaatannya berupa bahaya erosi dan fiksasi unsur-unsur hara. Jenis tanah lainnya yaitu andisol yang merupakan jenis tanah yang berkembang dari bahan induk seperti abu vulkan, batu apung dan sinder. Jenis tanah ini banyak mengandung mineral, memiliki daya menahan air yang tinggi, drainase cepat. Tanah andisol memiliki berat jenis tanah rendah dengan ketebalan solum antara 100-225 cm. biasanya berwarna hitam. Jenis tanah ini berporositas tinggi dengan permeabilitas rendah dan tergolong jenis tanah yang mudah tererosi.

Untuk menganalisis indikator ini digunakan skoring nilai jenis tanah dan jenis batuan wilayah penelitian. Pada tahap ini dilakukan overlay peta jenis tanah dan peta jenis batuan. Dari tumpang susun peta jenis tanah dan peta jenis batuan didefiniskan jenis tanah dan batuan yang sesuai untuk dijadikan lokasi TPAS berdasarkan kondisi hidrogeologi. Dari persebaran jenis tanah ini serta karakteristiknya, maka peneliti memberikan asumsi kelayakan atau tidaknya suatu wilayah untuk dijadikan lokasi TPAS berdasarkan karakteristiknya yang merujuk pada persyaratan lokasi TPAS yang sesuai SNI.

Untuk mendapatkan kondisi hidrogeologi, selain jenis tanah juga digunakan jenis batuan. Jenis batuan yang menggambarkan kondisi batuan yang tersebar di wilayah Kabupaten Lombok Timur. Jenis batuan yang tersebar di Kabupaten Lombok Timur yaitu, jenis batuan alluvium yang merupakan batuan endapan terdiri dari kerakal dan kerikil, pasir, lempung dan lumpur. Jenis batuan lainnya jenis batuan andesite yang merupakan batuan dengan tekstur halus, memiliki warna abu-abu hijau. Batuan jenis ini berasal dari lelehan lava gunung berapi yang membeku. Batuan andesit merupakan batuan berumur tua dengan tingkat kepadatan tinggi, memiliki pori-pori yang cukup padat dan porositas rendah. Untuk mengetahui lebih jelas jenis batuan ini dibantu dengan peta jenis batuan.

Batuan jenis lainnya adalah batuan basalt, batuan jenis ini merupakan hasil dari pendinginan lava gunung meletus sehingga dikategorikan batuan beku. Batuan basalt mengandung banyak mineral plagioklas dan piroksen dengan kandungan silica rendah. Batuan ini bersifat massif dan keras bertekstur afanitik yaitu batuan beku yang berbutir halus. Untuk mengetahui kesesuaian jenis batuan, peta jenis batuan ditentukan kelas kesesuaiannya. Kelas kesesuaian ini dilakukan berdasarkan pertimbangan kondisi lokasi yang sesuai untuk dijadikan TPAS. Dari kelas kesesuaian jenis batuan ini, kemudian ditumpang susunkan dengan kelas kesesuaian jenis tanah. Setelah didapatkan hasil overlay kedua peta tersebut, kemudian ditumpang susunkan lagi dengan peta hidrologi. Peta hidrologi 
yang digunakan untuk lebih spesifik pada jarak dari sumber air. Hasil gabungan peta-peta ini bisa diasumsikan untuk menganalisis lokasi yang sesuai untuk dijadikan lokasi TPAS berdasarkan kondisi geologi dan hidrogeologi. Kesesuaian jenis tanah dan batuan kemudian ditumpang susunkan lagi dengan peta hidrologi yang berkaitan dengan Cekungan Air Tanah (CAT) di Kabupaten Lombok Timur.

Berdasarkan hasil analisis tumpang susun tersebut didapatkan kelas kesesuaian lahan yaitu kelas kurang sesuai dan kelas tidak sesuai. Kelas kurang sesuai ini didapatkan dengan perhitungan kelas interval untuk indikator geologi dan hidrologi. Perhitungan ini dilakukan karena penentuan kelas kesesuaian dua indikator ini terlebih dahulu sebelum indikator selanjutnya. Indikator geologi dan hidrologi ditumpang susunkan menjadi satu kelas kesesuaian. Setelah dua indikator ini disesuaikan, selanjutnya ke indikator kemiringan lereng.

\section{Kemiringan lereng}

Lokasi TPAS tidak boleh terletak pada lokasi berbukit dan dengan lereng yang tidak stabil. Wilayah yang lebih sesuai untuk dijadikan lokasi TPAS merupakan wilayah landai. Wilayah dengan kemiringan yang curam akan rawan terkena longsoran terutama saat hujan atau rembesan air yang tinggi. Untuk menghidari hal itu, nilai kemiringan lereng yang sesuai untuk dijadikan lokasi TPAS dianjurkan di bawah $20 \%$. Kelas kemiringan lereng Kabupaten Lombok Timur bervariasi mulai dari $0 \%-15 \%$ yang mencakup daerah sepanjang pantai dan daerah dataran dari utara sampai selatan. Pada kelas kemiringan inilah yang sesuai untuk dijadikan lokasi TPAS.

Kelas kemiringan lereng 15\% - 25\% yang merupakan kelas kemiringan kedua. Pada daerah kemiringan ini, keadaan topograpi sudah tidak landai lagi. Berdasarkan kemiringan lereng yang sesuai untuk dijadikan TPAS, maka kelas kemiringan ini kurang sesuai untuk dijadikan lokasi TPAS. Kelas kedua pada kelas kesesuaian diberikan nilai skor dua. Kelas kemiringan ketiga merupakan kelas kemiringan pada lahan curam. Kemiringan lereng pada kelas ini berada diatas $25 \%$, kelas kemiringan ini tidak sesuai untuk dijadikan lokasi TPAS. Ketidak sesuaian untuk dijadikan TPAS karena berada pada daerah yang curam. Daerah dengan kemiringan besar tidak sesuai untuk dijadikan TPAS, untuk itu diberikan nilai skor satu. Kemiringan lereng di Kabupaten Lombok Timur dibagi menjadi tiga kelas kemiringan yaitu kelas sesuai dengan kriteria kelerengan di bawah 20\%, kelas cukup sesuai dengan kemiringan lereng antara 15\% sampai 20\% dan kelas tidak sesuai kemiringan diatas 20\%.

Kelas kesesuaian lokasi TPAS berdasarkan indikator kemiringan lereng kemudian ditumpang susunkan dengan peta kesesuaian lereng berdasarkan geologi dan hidrologi. Jadi, pada proses ini peta kesesuaian lokasi yang pertama ditumpang susunkan lagi dengan peta kemiringan lereng. Hasilnya merupakan peta kesesuaian dengan tiga indikator. Pada indikator ini, wilayah dengan kelas sesuai berada dibagian tengah ke selatan. Bagian ini memang relatif datar dan sesuai untuk dijadikan lokasi TPAS. Sedangkan wilayah bagian utara dikategorikan kelas tidak sesuai. Hal ini dikarenakan bagian utara kabupaten Lombok Timur merupakan wilayah pegunungan dengan kemiringan yang curam. Setelah digabungkan dengan dua indikator sebelumnya, didapatkan lokasi pada kelas sesuai semakin mengecil. Hanya sebagian kecil diperbatasan sebelah timur dan beberapa titik kecil dibagian selatan. Wilayah lainnya merupakan kelas kurang sesuai dan kelas tidak sesuai yang mendominasi. Setelah tiga indikator ini ditumpang susunkan, indikator lain dalam proses analisis adalah wilayah yang bukan merupakan cagar alam atau wilayah yang ditetapkan sebagai kawasan lindung.

4. Daerah lindung/cagar alam dan bahaya banjir

Lokasi TPAS tidak boleh berada pada wilayah yang sudah memiliki alokasi lain seperti daerah lindung/cagar alam/cagar budaya. Berdasarkan hasil proses overlay indikator sebelumnya, wilayah dengan kelas sesuai bukan merupakan wilayah lindung ataupun cagar alam. Jadi, diasumsikan wilayah yang sesuai pada indikator sebelumnya masih bisa dikategorikan wilayah dengan kelas sesuai.

5. Jarak terhadap lapangan terbang

Jarak lokasi TPAS dari lapangan terbang harus lebih dari 3000 meter. Indikator ini digunakan karena landfilling yang menerima limbah organik dapat menarik kehadiran burung yang dapat mengganggu kegiatan penerbangan. Selain itu, TPAS bisa menimbulkan dampak negatif terkait bau tidak sedap yang menyengat dan menyebabkan kesan estetika yang tidak baik bagi pengunjung 
bandara. Kabupaten Lombok Timur sendiri tidak memiliki lapangan terbang. Untuk itu, indikator lapangan terbang tidak mempengaruhi penentuan lokasi TPAS yang akan dibangun. Bisa dikatakan semua wilayah Kabupaten Lombok Timur memungkinkan untuk dijadikan lokasi TPAS berdasarkan indikator jarak dari lapangan terbang.

Setelah semua indikator berdasarkan tahapan regional sudah dianalisis satu persatu. Hasil akhir dari analisis pentuan lokasi TPAS berdasarkan tahap regional ini menunjukkan wilayah dengan kelas sesuai di Kabupaten Lombok Timur sangat kecil. Wilayah yang sesuai ada pada tiga wilayah administrasi. Wilayah yang sesuai berdasarkan tahap regional hanya ada di wilayah administrasi kecamatan Pringgabaya, kecamatan Keruak dan kecamatan Jerowaru. Namun, dari tiga wilayah administrasi tersebut luasan daerah yang sesuai tidak terdapat pada seluruh wilayah. Wilayah terluas hanya terdapat pada kecamatan Pringgabaya. Dua kecamatan lain memiliki luasan wilayah yang sangat sedikit. Peta hasil tahap regional ini dapat dilihat pada gambar 1.

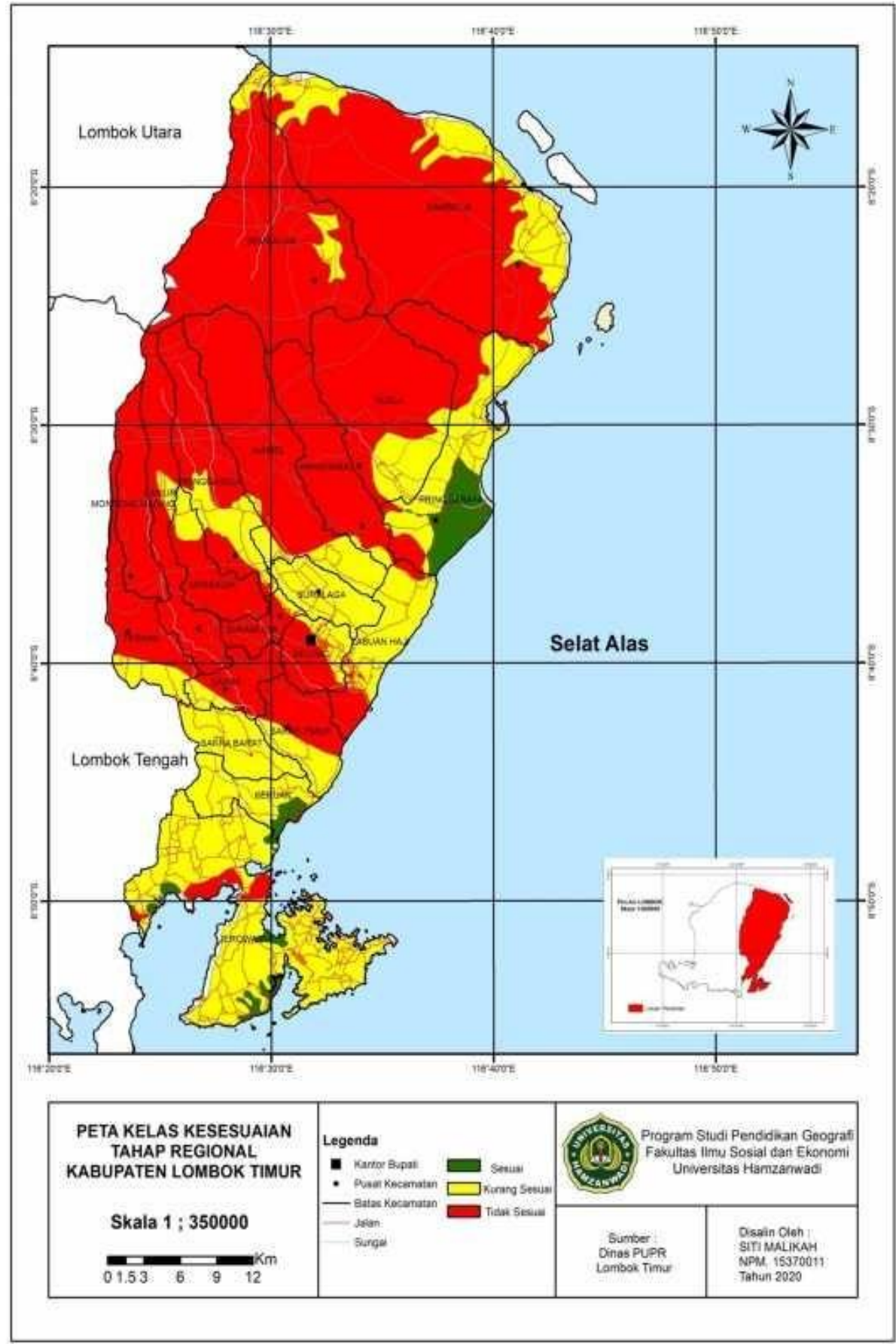

Gambar 1. Peta Kelas Kesesuaian Lahan Tahap Regional (Sumber: Hasil olahan data primer, 2020) 


\section{Tahap Penyisihan}

Setelah didapatkan hasil analisis penentuan lokasi TPAS berdasarakan tahap regional, tahap selanjutnya adalah tahap penyisih. Tahap ini berfungsi menyeleksi kembali wilayah yang sudah didapatkan pada kelas sesuai di tahap regional. Tahap penyisih difokuskan pada wilayah yang sesuai berdasarkan kriteria regional. Pada tahap penyisih ini, wilayah yang dianalisis difokuskan pada kecamatan Pringgabaya, Keruak dan Jerowaru. Ketiga wilayah administrasi ini yang memungkinkan untuk dibangun TPAS di Kabupaten Lombok Timur. Adapun kriteria penyisih yang digunakan adalah Batas Administrasi, Curah Hujan, Kepadatan Penduduk dan lainnya.

Kriteria pada tahap penyisih ini menggunakan nilai dan bobot pada setiap kriteria. Nilai dan bobot yang digunakan sudah ditetapkan berdasarkan SNI. Pada tahap penyisih ini, dilakukan penilaian secara mandiri pada wilayah yang sesuai berdasarkan tahap regional. Curah hujan dan kepadatan penduduk. Wilayah yang sesuai untuk dijadikan lokasi TPAS adalah wilayah dengan curah hujan dibawah $500 \mathrm{~mm} /$ tahun. Hal ini dikarenakan, lokasi TPAS diharapkan tidak cepat tergenang hujan sehingga bisa membawa permasalahan lain. Curah hujan yang tinggi, bisa saja menyebabkan sampah yang terkumpul basah dalam waktu yang lama. Kemudian akan menimbulkan bau yang tidak sedap, shingga pendirian TPAS pada lokasi tersebut harus dihindari. Wilayah yang akan dijadikan lokasi TPAS juga tidak boleh berada pada kawasan padat penduduk. Karena hal ini bisa menyebabkan permasalahan penduduk baik itu bau yang menyengat ataupun distribusi sampah yang bisa saja ke pemukiman masyarakat.

Adapun dari tiga wilayah administrasi, hanya ada satu wilayah kecamatan yang memungkinkan untuk dianalisis kembali yaitu wilayah kecamatan Pringgabaya. Dua wilayah lain seperti Keruak dan Jerowaru tidak dipilih karena keduanya berada pada wilayah perbatasan administrasi. Selain itu, kedua wilayah ini memiliki luasan lokasi yang sangat kecil. Kecamatan Pringgabaya, tidak berada diwilayah perbatasan administrasi. Wilayah inipun hanya meliputi empat desa yaitu desa Krumut, Pohgading, Batu Yang dan Pringgabaya. Adapun luasan wilayah, desa Pringgabaya merupakan desa dengan wilayah terluas dan kepadatan penduduk terkecil. Setelah Pringgabaya selanjutnya desa Batu Yang dengan kepadatan terendah ketiga dari desa lainnya. Diurutan ketiga terluas yaitu desa Pohgading dengan kepadatan tertinggi. Selanjutnya desa Krumut merupakan desa dengan luasan terkecil dan kepadatan tingkat kedua setelah Pringgabaya. Terkait dengan lalu lintas dengan bobot tiga poin, desa Pringgabaya memiliki lalu lintas terpadat karena merupakan ibu kota kecamatan. Di damping itu, di desa ini juga terdapat pasar umum yang besar. Hal ini juga berkaitan dengan jalan masuk transportasi yang membawa sampah ke lokasi. Termasuk juga dengan kebisingan dan bau. Bobot dan nilai masing-masing desa dapat dilihat pada tabel 1 .

Tabel 1. Hasil Analisis Tahap Penyisihan

\begin{tabular}{clcccc}
\hline \multirow{2}{*}{ No } & \multirow{2}{*}{ Parameter } & \multicolumn{4}{c}{ Wilayah } \\
\cline { 3 - 6 } & & Krumut & Pohgading & Batu Yang & Pringgabaya \\
\hline 1 & Kaitan dengan pemanfaatan airtanah & 15 & 15 & 15 & 15 \\
2 & Tanah penutup & 4 & 4 & 4 & 4 \\
3 & Jalan menuju lokasi & 50 & 50 & 50 & 50 \\
4 & Transportasi sampah & 25 & 25 & 25 & 25 \\
5 & Jalan masuk & 4 & 4 & 4 & 20 \\
6 & Lalu lintas & 24 & 24 & 24 & 9 \\
7 & Tata guna lahan & 25 & 25 & 25 & 25 \\
8 & Pertanian & 3 & 3 & 3 & 3 \\
9 & Kebisingan dan bau & 10 & 10 & 10 & 10 \\
10 & Estetika & 3 & 3 & 3 & 3 \\
& Total & 163 & 163 & 163 & 164 \\
\hline
\end{tabular}

Sumber: Hasil olahan data primer, 2020.

Berdasarkan tabel 1 diketahui bahwa keempat desa tersebut memiliki nilai yang tidak terlalu berbeda jauh. Hal ini disebabkan karena secara umum keempat desa tersebut berada dalam satu wilayah administrasi kecamatan. 


\section{Tahap Rekomendasi}

Berdasarkan hasil analisis pada tahap analisis maka disimpulkan sekaligus dapat direkomendasikan bahwa lokasi TPAS baru di kabupaten Lombok Timur layak dibangun di wilayah administrasi Kecamatan Pringgabaya khususnya di Desa Peringgabaya. Hal ini mengingat Desa Peringgabaya mendapatkan skor tertinggi jika dibandingkan tiga desa lainnya di wilayah kecamatan Peringgabaya. Lokasi yang direkomendasikan ini masih perlu catatan lain seperti Kecamatan Pringgabaya yang secara umum merupakan wilayah ramai, apalagi termasuk jalur penyeberangan utama jalur laut. Lokasi yang terpilih ini juga berada di bagian Utara Kabupaten Lombok Timur, sehingga perlu pertimbangan untuk sampah yang bersumber dari bagian Selatan. Hal ini berkaitan dengan pengangkutan dan transportasi sampah dari sumber hasil sampah menuju tempat terakhir. Jika dipertimbangan hal-hal tersebut, memang ada ketidak sesuaian pada lokasi yang terpilih. Dengan demikian perlu dilakukan pengkajian lanjutan sehingga dapat ditemukan solusi terbaik untuk mengatasi berbagai kendala tersebut.

\section{SIMPULAN}

Berdasarkan hasil analisis pada setiap tahapan baik tahapan regional, penyisihan dan tahapan rekomendasi, dapat disimpulkan bahwa lokasi yang sesuai untuk pendirian lokasi TPAS adalah Desa Peringgabaya Kecamatan Pringgabaya dengan skor nilai tertinggi yaitu 164. Sedangkan untuk kelas Tidak Sesuai adalah Kecamatan Keruak dan Jerowaru karena pada tahap penyisih memiliki total nilai lebih rendah jika dibandingkan dengan Kecamatan Pringgabaya. Lokasi yang lainnya adalah lokasi-lokasi yang kurang sesuai untuk pendirian TPAS yang baru.

\section{DAFTAR PUSTAKA}

Anggaraini, F. (2016). Pengembangan Standar Nasional Indonesia (SNI) 03-3421-1994 untuk Standarisasi Pemilihan Lokasi TPAS Regional. Laporan penelitian. Bandung. Puslitbang Perumahan dan Pemukiman.

Apriyeni, B. A. R. (2008). Analisis Tingkat Kesesuaian Lahan untuk Pengembangan Tanaman Jarak Pagar di Kabupaten Lombok Timur Menggunakan Sistem Informasi Geografis (SIG). Skripsi. Yogyakarta. Universitas Negeri Yogyakarta.

Badan Litbang PU. (1994). SNI 03-3241-1994 Tentang Tata Cara Pemiliban Lokasi Tempat Pembuangan Akhir Sampah. Jakarta. Badan Standarisasi Nasional.

Badan Pusat Statistik NTB. (2020). Jumlah Penduduk Menurut Kabupaten/Kota dan Jenis Kelamin di Provinsi Nusa Tenggara Barat, Tahun 1990, 1993-2020. Diakses pada tanggal 20 Juni 2020 dari https://ntb.bps.go.id/linkTableDinamis/view/id/63.

Dinas Lingkungan Hidup dan Kebersihan (DLHK) Lotim. (2018). TPA Ijo Balit. Diunduh di http://dlhk.lomboktimurkab.go.id/baca-berita-162-tpa-ijo- balit.html pada tanggal 19 Januari 2019.

Handono, M. (2010). Model Pengelolaan Tempat Pemrosesan Akhir (TPA) Sampah Secara Berkelanjutan di TPA Cipayung Kota Depok, Jawa Barat. Disertasi. Bogor: Institut Pertanian Bogor.

Hasibuan, R. (2016). Analisis Dampak Limbah/Sampah Rumah Tangga Terhadap Pencemaran Lingkungan Hidup. Jurnal Ilmiah Advokasi, 4(1), 42-52.

Huda, M. A. N., Hadi, H., \& Subhani, A. (2020). Pengelolaan Sampah di Sepanjang Sempadan Sungai Kelurahan Pancor dan Kelurahan Sekarteja. Geodika: Jurnal Kajian Ilmu dan Pendidikan Geografi, 4(1), 95-106.

Inside Lombok. (2020). Volume Sampah di Lotim 515 Ton Per Hari. Diakses pada tanggal 20 Juni 2020 darihttps://insidelombok.id/berita-utama/volume-sampah-di-lotim-515-ton perhari/\#: :text=Lombok $\% 20$ Timur $\% 20$ (Inside $\% 20$ Lombok) $\% 20 \% \mathrm{E} 2 \% 80 \% 93$,rata $\% 20 \mathrm{yang} \%$ 20diangkut $\% 20$ setiap $\% 20$ harinya. 
Irawan, A. B., \& Yudono, A. R. A. (2014). Studi Kelayakan Penentuan Tempat Pemrosesan Akhir Sampah (TPA) di Pulau Bintan Propinsi Kepulauan Riau. Jurnal Ilmu Lingkungan, 12(1), 1-11.

Mahyudin, R. P. (2017). Kajian Permasalahan Pengelolaan Sampah dan Dampak Lingkungan di TPA (Tempat Pemrosesan Akhir). Jukung (Jurnal Teknik Lingkungan), 3(1), 66-74 .

Rachmah, Z., Rengkung, M.M., \& Lahamendu, V. (2018). Kesesuaian Lahan Permukiman di Kawasan Kaki Gunung Dua Sudara. Jurnal Spasial, 5(1), 118-129.

Shofa, R., \& Hadi, H. (2017). Studi Sanitasi Lingkungan Permukiman Nelayan di Desa Tanjung Luar Kecamatan Keruak Kabupaten Lombok Timur. Geodika: Jurnal Kajian Ilmu dan Pendidikan Geografi, 1(2), 22-33.

Suara NTB. (2017). TPA Ijo Balit Terancam “Overload” Tumpukan Sampah Capai Tujub Meter. Diunduh di https://www.suarantb.com/pilihan.editor/2017/10/. pada tanggal 19 Januari 2019.

Sudradjat, H.R. (2007). Mengelola Sampah Kota. Jakarta: Penebar Swadaya. 